\title{
REVIEW
}

\section{Why do so many trials of vitamin D supplementation fail?}

\author{
Barbara J Boucher \\ Blizard Institute, Barts \& The London school of Medicine \& Dentistry, Queen Mary University of London, London, UK
}

Correspondence should be addressed to B J Boucher: bboucher@doctors.org.uk

\begin{abstract}
Our knowledge of vitamin $D$ has come a long way since the 100 years it took for doctors to accept, between 1860 and 1890, that both sunlight and cod liver oil (a well-known folk remedy) cured and prevented rickets. Vitamins $D_{2} / D_{3}$ were discovered exactly a hundred years ago, and over the last 50 years vitamin $D$ has been found to have many effects on virtually all human tissues and not just on bone health, while mechanisms affecting the actions of vitamin $D$ at the cellular level are increasingly understood, but deficiency persists globally. Observational studies in humans have shown that better provision of vitamin $\mathrm{D}$ is strongly associated, dose-wise, with reductions in current and future health risks in line with the known actions of vitamin D. Randomised controlled trials, commonly accepted as providing a 'gold standard' for assessing the efficacy of new forms of treatment, have frequently failed to provide supportive evidence for the expected health benefits of supplementation. Such RCTs, however, have used designs evolved for testing drugs while vitamin $\mathrm{D}$ is a nutrient; the appreciation of this difference is critical to identifying health benefits from existing RCT data and for improving future RCT design. This report aims, therefore, to provide a brief overview of the evidence for a range of non-bony health benefits of vitamin $D$ repletion; to discuss specific aspects of vitamin $D$ biology that can confound RCT design and how to allow for them.
\end{abstract}

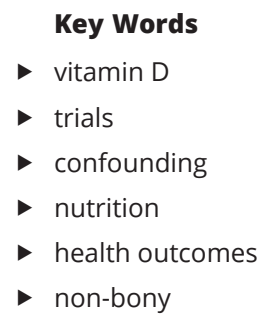

Endocrine Connections (2020) 9, R195-R206

\section{Associations of vitamin D status with health outcomes}

Cross-sectionally, vitamin D cures/prevents rickets but populations remain deficient $(1,2)$ as assessed by serum 25-hydroxyvitamin D concentration (25(OH)D), which is inversely associated with obesity, immunity, the rates of many infections, cancers (e.g. breast and colorectal), and cancer mortality, with chronic disorders such as insulin resistance, metabolic syndrome (Syndrome X), type 2 diabetes (T2DM), acute cardiovascular events (e.g. myocardial infarction) and with disorders of pregnancy (stillbirth, small for date babies, pre-term births and gestational diabetes) $(3,4,5,6,7,8,9,10)$.

Prospectively, higher vitamin D status (serum $25(\mathrm{OH}) \mathrm{D}$ concentration) predicts later reductions in the risks of many disorders, dose-wise. For example, of metabolic syndrome after $\sim 10$ years, of T2DM after $\sim 10$ years, of T1DM after $3-5$ years (in early life), of CVD events and in overall CVD mortality. Lower incidence and mortality rates are also reported for some cancers (e.g. breast and colorectal). Such predictive associations may seem surprising when serum 25(OH)D is well-known to vary with season but between 30 and $50 \%$ of an individual's $25(\mathrm{OH}) \mathrm{D}$ is heritable, based on genome-wide association study data, while baseline $25(\mathrm{OH}) \mathrm{D}$ predicted $\sim 50 \%$ of $25(\mathrm{OH}) \mathrm{D}$ remeasured after 14 years $(11,12,13,14,15$, $16,17)$. 


\section{Vitamin D in evolution}

Ergocalciferol and cholecalciferol (vitamins $\mathrm{D}_{2}$ and $D_{3}$ ) first appeared in early unicellular ocean dwelling organisms and are thought to have allowed their survival by providing protection from the intensive UVB reaching the earth's surface, its energy being dissipated as it destroyed these compounds. Synthesis of ergocalciferol persists in plants and fungi and of cholecalciferol in most animals, though some acquire it solely through the food chain (18). Both forms of vitamin D are fat soluble and biologically inert. Further references to vitamin D in this report are limited to cholecalciferol $\left(\mathrm{D}_{3}\right)$ unless otherwise stated.

\section{Production of vitamin D}

Cholecalciferol is synthesised in the skin under the influence of UVB (wavelength $270-300 \mathrm{~nm}$ ) in sunlight that reaches the earth's surface in the greatest amounts in equatorial regions and in the lowest amounts near the poles. Skin synthesis is reduced by skin pigmentation, melanin acting as a sunscreen in those evolving in equatorial Africa. The evolution of fairer skin as humans migrated towards the polar regions, allowing increased skin synthesis despite less available UVB, was important in human survival following those migrations since little vitamin $\mathrm{D}$ is provided in foods, for example, in egg yolk, oily sea and fresh-water (but not farmed) fish and fortified foods, but in much smaller amounts than is induced in vivo by moderate skin exposure to UVB from summer sunshine $(19,20)$.

\section{The common problem of vitamin D inadequacy}

Modern lifestyles reduce our exposure to sunshine due to working, exercising and travelling behind glass, which blocks UVB transmission, aggravated by widespread sunavoidance aimed at reducing skin ageing and skin cancer risks, by the increasing use of sunscreens and cosmetics containing sun-blockers and by the continuing migration of dark skinned peoples to temperate zones. Skin synthesis also falls with age, increasing the risks of deficiency in the elderly $(20,21,22)$. It is no surprise, therefore, that there is currently a global problem of vitamin D inadequacy with the reappearance of rickets and osteomalacia, the classic bone diseases seen in vitamin D deficiency (23). Though most countries provide guidance on recommended daily intakes of vitamin D, especially in infants and children, actual intakes are often inadequate for bone health, especially in dark skinned migrant communities, while the intakes needed to reduce non-skeletal health risks of deficiency are increasingly recognised as being higher than those for bone health (24).

\section{Route from inert vitamin D to hormonal activity}

Both vitamins $\mathrm{D}_{2}$ and $\mathrm{D}_{3}$ are inert and fat soluble, best absorbed when eaten with fatty foods, and stored in fatty tissues, though absorption falls with ageing. Two-stage hydroxylation of the inert vitamin leads to its activation; first, a specific 25-hydroxylase (CYP2R1, found mainly in the liver, adds an -OH group at the 25-position forming 25-hydroxyvitamin D (25(OH)D). This metabolite binds to specific binding proteins (and albumen) in the blood stream and leaves the circulation with a half-life of 2-17 weeks, the half-life increasing mainly with baseline vitamin D status but also varying with genetics (25). Vitamin D provision from skin synthesis raises serum 25(OH)D concentrations faster and to higher levels than oral intakes, reflecting the 25-hydroxylation of vitamin D in the skin (26), while absorption of $\mathrm{D}_{3}$ from skin may be faster than from the gut.

Circulating concentrations of $25(\mathrm{OH}) \mathrm{D}$ are generally accepted as reflecting body stores of vitamin D (vitamin D status), mainly because they relate closely to health outcomes cross-sectionally and prospectively, as mentioned earlier. $25(\mathrm{OH}) \mathrm{D}$ is the substrate taken up by cells where a second hydroxylation by a specific $1 \alpha$-hydroxylase (CYP-27B1) forms calcitriol $\left(1 \alpha, 25(\mathrm{OH})_{2}\right.$ vitamin D), first identified in the kidney, with hormonal effects modulating processes relevant to bone health. This activation is now known to occur in all target tissues, where locally produced calcitriol has autocrine and paracrine functions. Renal calcitriol production is regulated by factors including parathyroid hormone, FGF23 (fibroblast growth factor 23), serum phosphate and prolactin. In other target tissues, all of which express both the activating hydroxylase and the vitamin D receptor, calcitriol production is mainly up-regulated by serum $25(\mathrm{OH}) \mathrm{D}$ concentration and down-regulated by the specific catabolic 24-OHase, explaining the value of serum 25(OH)D data for evaluating vitamin D 'status' and for assessing the effects of changes in vitamin D status on health risks and health outcomes in vivo. Circulating calcitriol concentrations, in contrast, are tightly regulated, do not reflect vitamin D status, are unhelpful in diagnosing

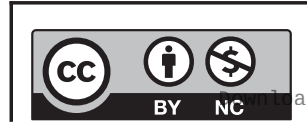

This work is licensed under a Creative Commons Attribution-NonCommercial 4.0 International License. ded from Bioscientifica.com at 04/26/2023 01:51:04AM 
vitamin D deficiency and rarely relate closely to human disease risks, though it is calcitriol that effects the actions of vitamin D in the tissues $(27,28)$. Both skin synthesis of vitamin $\mathrm{D}$ and its activation are self-regulated, avoiding excessive production of vitamin $\mathrm{D}_{3}$ or of calcitriol. Thus, vitamin $\mathrm{D}$ toxicity cannot be induced by sunshine in health, though hugely excessive intakes can overwhelm the regulatory system causing hypercalcaemic toxicity. Rare lymphoid disorders (e.g. sarcoidosis), with loss of local tissue regulation, especially in macrophages, allow unregulated calcitriol overproduction ('vitamin D hypersensitivity') (29).

\section{Induction of biological effects of vitamin D in target tissues}

There are three major mechanisms by which calcitriol induces its effects on the tissues. In brief, the first mechanism follows non-genomic binding of calcitriol to vitamin D receptors (VDRs) in cell wall caveolae causing rapid rises in intracellular calcium concentrations which, in turn, activate rapid effects (30). For example, this mechanism triggers early insulin release in response to rise in blood glucose through activation of certain beta cell endopeptidases that release insulin from pancreatic islet beta cell storage granules by splitting insulin from proinsulin and raising circulating insulin within minutes (31). The second and slower mechanism is induction of changes in the rates of synthesis of gene products following the binding of ligand (calcitriol)-bound VDRs (commonly complexed with retinol-X receptors), to vitamin $\mathrm{D}$ response elements (VDREs) in the promoter regions of many hundreds of target genes; multiple genes show seasonal variation in expression, many relating to varying vitamin D status $(32,33)$. One example is the slower increase in islet beta cell insulin synthesis, during phase 2 of the insulin response to glucose, peaking 20-30 min after glycaemia begins to rise. The third mechanism is through epigenetic effects of vitamin D at different stages in development which silence various metabolic and developmental processes temporarily where appropriate (28), and that appear to be especially important in early life. Epigenetic effects are induced through three main mechanisms (many being reversible), either by altering gene methylation, by changing the configuration of histone cores around which chromatid chains are wound within the chromosomes, or by inducing changes in noncoding genetic RNA (34).

\section{Many mechanistic effects improve function or reduce damage in non-skeletal tissues}

Though beyond the scope of this discussion, there are many well-understood actions due to the rapid nongenomic or slow genomic effects of calcitriol mentioned above, that are protective. For obesity, T2DM and hypertension these include effects on the pancreas, liver, and muscle that reduce abnormal insulin resistance, protect beta cell function and protect against arterial wall damage $(35,36,37,38,39,40,41)$. In the immune system they protect against bacterial and viral infections, excessive acquired immune responses and more generally against inflammatory tissue damage $(42,43,44,45,46,47$, $48,49,50,51)$. Other beneficial effects include inhibition of cancer development and progression (52, 53, 54, 55), promotion of normal foetal development (notably of the brain) and of healthy pregnancy through direct effects of maternal vitamin D status and epigenetic effects of maternal vitamin $\mathrm{D}$ status on the developing foetus $(56,57,58,59)$.

In view of these well-understood effects of vitamin D and of the consistent associations of poor vitamin D status with increase in health risks in the areas mentioned, one has to wonder whether the failures of RCTs to show the expected health benefits with supplementation might reflect a degree of confounding of those RCTs, rather than that all of the mechanisms identified as being active in human tissues are irrelevant to human health. This concern is strengthened by the fact that provision of vitamin $\mathrm{D}$ in pet foods, especially for domestic pets and carnivores unable to synthesie the vitamin efficiently, is now a standard practice, as it is in zoos and for animals farmed under partly indoor conditions, including ruminants and poultry, because of the evident health benefits (https://www.dsm.com/markets/anh/en_US/ Compendium/companion_animals/vitamin_D.html).

\section{Potential confounders of vitamin D RCTs}

\section{Design defects}

First, vitamin D is a nutrient, not a drug, and the graphs for changes in biological effects as vitamin D provision increases from nil to adequacy are not linear but S-shaped, both for rise in serum $25(\mathrm{OH}) \mathrm{D}$ with better vitamin $\mathrm{D}$ provision and for increase in the effects of increase in serum 25(OH)D (60). These S-shaped response curves mean that, in deficiency, no changes in function/benefits will be seen

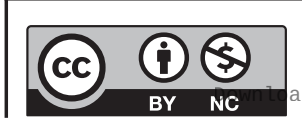

This work is licensed under a Creative Commons Attribution-NonCommercial 4.0 International License. ded from Bioscientifica.com at 04/26/2023 01:51:04AM 
unless $25(\mathrm{OH}) \mathrm{D}$ values are raised from deficiency onto the steep part of the $\mathrm{S}$ curve for the effect(s) of interest and that when baseline $25(\mathrm{OH})$ Ds are already on the upper plateau of the $S$ curve, extra provision will not induce benefits. Thus, in RCTs, where identical doses are given to everyone in the treatment arm, the doses will be too small to normalise serum $25(\mathrm{OH}) \mathrm{D}$ in many deficient subjects and unable to induce significant changes in effects/outcomes in 'replete' subjects. Thus, the chances of seeing measurable health benefits will be lost in significant proportions of study subjects in the treatment arm unless results can be picked out for those who were deficient at baseline, and, ideally, made replete during the RCT. Most workers, however, have simply aimed to seek health benefits in the general population. The need to allow for this confounder is well-illustrated by a study of individual participant data retrieved from 25 previous RCTs for reduction of upper respiratory tract infection rates by supplementation where re-examination by metaanalysis used baseline $25(\mathrm{OH}) \mathrm{D}$ data available for $\sim 11,000$ participants stratified by 'status'. The overall hazard ratio (HR) for that cohort was 0.88 (95\% CI; 0.81-0.96), but for subjects with a baseline $25(\mathrm{OH}) \mathrm{D}<25 \mathrm{nmol} / \mathrm{L}$ it was 0.30 (95\% CI; 0.17-0.53) for those on daily/weekly dosing (but not in those on interval doses using large boluses (which have previously been reported to induce adverse effects on bone health) $(61,62)$. Other analyses using stratified $25(\mathrm{OH}) \mathrm{D}$ data have shown improvements in insulin resistance and diabetic control, and in a meta-analysis of RCT data on supplementation in T2DM (63). In prediabetes fasting plasma glucose fell with supplementation in subjects with baseline BMIs $<25$ or $25(\mathrm{OH})$ Ds of $50-75$ $\mathrm{nmol} / \mathrm{L}$, insulin resistance was reduced with baseline $25(\mathrm{OH}) \mathrm{Ds}>75 \mathrm{nmol} / \mathrm{L}$ and reductions in T2DM risk were found for subjects with BMIs $<25$ or $25(\mathrm{OH})$ Ds of $50-75$ $\mathrm{nmol} / \mathrm{L}$. These benefits were largest with higher dosages (2000 IU/day) and when supplementation did not include calcium $(63,64)$.

\section{Variations in 25(OH)D effect thresholds}

This phenomenon is another potential confounder of RCT analyses (65). Bone health, for example, is generally accepted as being protected when serum $25(\mathrm{OH}) \mathrm{D}$ values are at least $50 \mathrm{nmol} / \mathrm{L}$, as assessed from the available evidence in 2011 by the North American Institute of Medicine in 2011 (66).

While this threshold for bone health continues to be used, higher thresholds of serum 25(OH)D concentration are emerging for non-skeletal health benefits. For example, abnormal insulin resistance in deficient subjects with normoglycaemia was not reduced unless $25(\mathrm{OH}) \mathrm{D}$ values reached at least $80 \mathrm{nmol} / \mathrm{L}(67)$. Other suggested thresholds lie between 50 and $100 \mathrm{nmol} / \mathrm{L}$. Thus, failure to ensure that the necessary thresholds are reached, and maintained, for the health outcome(s) of interest during RCTs is a likely confounder. Avoidance of this problem would require checking $25(\mathrm{OH}) \mathrm{D}$ values during RCTs so that individual dosages could be adjusted for maintenance of 25(OH)Ds at or above the appropriate thresholds. Furthermore, if binary analyses of outcomes are made for $25(\mathrm{OH}) \mathrm{D}$ values, for example, for outcomes in subjects reaching $25(\mathrm{OH}) \mathrm{D}$ values more or less than $50 \mathrm{nmol} / \mathrm{L}$, when the actual effect threshold is considerably higher, the findings would be confounded by including many inadequately supplemented subjects in the stratum of data hypothesised, a priori, as likely to benefit from supplementation. However, specific thresholds could be detected by using various potential cut-offs in such comparisons.

\section{Non-supplemental vitamin D intakes during RCTs and varying absorption}

Vitamin D is normally acquired through skin synthesis and from food, but these sources are rarely controlled for. Continued self-supplementation during RCTs can contribute to confounding of RCT data analyses, but is often allowed (e.g. in the VITAL study) (68). Higher socio-economic status is clearly associated with healthier lifestyles, including increases in physical activity, access to healthier foods and more sunshine holidays. These factors are associated with higher vitamin D status and usually allowed for in RCT data analyses, even though increased supplement usage is not.

Absorption of supplemental vitamin D varies with how much fat it is taken with, but RCT subjects are not normally asked to take supplements in any specific way. Absorption of vitamin D becomes less efficient with age, but compensatory dose increases are not provided (69). Importantly also, $\times 1.5$ - and $\times 2-3$-fold increases in vitamin D dose are needed in overweight and obese people respectively, to achieve adequate $25(\mathrm{OH}) \mathrm{D}$ rises matching those in the non-obese, but are not normally provided in RCTs (70). None of these problems, common in vitamin D RCTs, would matter if RCTs were organised by baseline and achieved 25(OH)D values, monitoring status and adjusting doses to ensure planned target vitamin D status

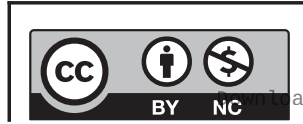

This work is licensed under a Creative Commons Attribution-NonCommercial 4.0 International License. ded from Bioscientifica.com at 04/26/2023 01:51:04AM 
is maintained throughout (71). Additionally, since it is not ethically acceptable to leave controls deficient during longer RCTs, they are often given locally advised daily recommended supplements, possibly affecting repletion in some control subjects.

\section{Other dietary factors modulating vitamin D efficacy}

These include calcium intake, sometimes allowed for or given as additional supplementation (69). Calcium is an important nutrient since childhood rickets can be healed by adequate calcium intake; however, for non-bony effects, on the cardiovascular system for example, where higher dietary calcium intakes have been reported to have beneficial effects on CVD outcomes, supplemental calcium may have adverse effects $(72,73)$. Other dietary factors rarely assessed include magnesium, commonly deficient, which is essential for optimal enzyme function, including those in the vitamin $\mathrm{D}$ axis and signalling pathways (74). Vitamin A is necessary for vitamin D signalling but excessive intakes, common in developed countries, can antagonise vitamin D's effects, perhaps through annexation of the retinoid X receptor (RXR) to form RXR:RAR complexes (75). Experimentally, vitamin D toxicity is mitigated by large doses of vitamin $\mathrm{A}$ and in humans supplemental vitamin A can abolish health benefits of vitamin D supplementation $(76,77)$. Other interactions are reported for vitamin $\mathrm{K}$ (and possibly other vitamins) (78). Intakes of these nutritional factors should, therefore, be allowed in RCT analyses, ideally through dietary data collection for automated in silico analyses of those intakes in both arms of vitamin D RCTs.

\section{Stratification by vitamin D 'status' or by effect thresholds?}

Most RCT analyses have used baseline (+/- achieved) vitamin $\mathrm{D}$ status to stratify their analyses using existing definitions of deficiency, for example, $<25 \mathrm{nmol} / \mathrm{L}$ in the United kingdom (where $25-75 \mathrm{nmol} / \mathrm{L}=$ insufficiency), $<50 \mathrm{nmol} / \mathrm{L}$ in North America's Institute of Medicine guidelines and $<75 \mathrm{nmol} / \mathrm{L}$ in the US Endocrine Society guidelines $(66,79,80)$. Other thresholds have been suggested and $25(\mathrm{OH}) \mathrm{D}$ thresholds for plateaus in serum parathyroid hormone concentrations also vary, an observation of as yet unknown significance (81). Thresholds for outcomes suggested from RCT data rarely match such definitions, which will perturb outcome analyses, as discussed above. Additionally, different definitions of 'status' make it difficult to compare findings or to gather RCT data for meta-analysis unless individual participant data (IPD) is available. The use of tertiles, quintiles may sound a reasonable way to avoid these problems but for health benefits with specific $25(\mathrm{OH}) \mathrm{D}$ thresholds this methodology is unlikely to produce stratification matching specific thresholds, so that this methodology could obscure health benefits. Many of these aspects of RCT data analysis could be better allowed for once assay data harmonisation becomes routine and effect thresholds are identified and agreed internationally.

\section{Factors affecting the consistency of 25(OH)D assay measurements}

25(OH)D data has been widely used in observational studies and RCTs, but there has been little allowance for the many problems inherent to these measurements. First, the variability of the widely used immunoassay methodology is considerable, with cumulative variances of $7-19 \%$ in one study (82). This problem has been reduced by increasing compliance of laboratories world-wide with the international quality control scheme, DEQAS (83). The increasing use of the current 'gold standard' HPLC-TMS assay methodology (high pressure liquid chromatography-tandem mass spectroscopy) produces 25 $(\mathrm{OH}) \mathrm{D}$ concentrations higher than immunoassay results by +3 to $+6 \%$, and occasionally by up to $+33 \%$ ( 84 , $85)$. This problem means that data from various studies, including RCTs, cannot always be compared or used in meta-analyses unless stored samples from older studies are available for re-assay with HPLC-TMS methodology, allowing assay 'Harmonisation' (86). These differences in $25(\mathrm{OH}) \mathrm{D}$ assay values also mean that $25(\mathrm{OH}) \mathrm{D}$ cutoff levels used to define 'status' need to be updated, and agreed internationally, if future study data is to be used in comparisons, for meta-analyses, or for international agreement on effect thresholds - a matter likely to increase in importance once effect thresholds can be used to define degrees of vitamin D adequacy for different disorders.

\section{Serum 25(OH)D values vary with genetic polymorphisms}

Variants are common in genes relating to D binding proteins and in genes regulating vitamin $\mathrm{D}$ activation. Importantly, many of these variants affect the size of the

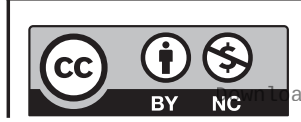

This work is licensed under a Creative Commons Attribution-NonCommercial 4.0 International License. ded from Bioscientifica.com at 04/26/2023 01:51:04AM via free access 
increase in $25(\mathrm{OH}) \mathrm{D}$ with supplementation and these variations can be as large or larger than $25(\mathrm{OH}) \mathrm{D}$ assay variability. Some gene effects are only seen in the winter, being swamped by summertime increase in $25(\mathrm{OH}) \mathrm{D}(87$, 88). Few studies allow for these genetic variations as yet but, since they contribute to the provision of circulating 25(OH)D substrate to local target tissues for activation, they must modulate vitamin D efficacy. Adjustment for these gene variants, therefore, may well become routine in future RCT analyses.

\section{Free vs bound 25-hydroxyvitamin D}

Most 25(OH)D in the circulation is bound to the binding proteins already mentioned but small amounts remain unbound or 'free'. The relative importance of unbound versus bound $25(\mathrm{OH}) \mathrm{D}$ uptake by different target tissues remains unclear but may become more important as this factor becomes better understood (89).

\section{Newer findings on disorders directly affecting serum 25(OH)D concentrations}

In addition to the factors discussed above, it has been reported that the specific hepatic 25-hydroxylase enzyme, previously assumed to be constitutively expressed, is down-regulated in obesity (and diabetes). Additionally, expression of the $24(\mathrm{OH})$ ase specifically catabolic for calcitriol and its precursor is increased in obesity, supporting Mendelian randomisation reports that obesity reduces serum $25(\mathrm{OH}) \mathrm{D}$ rather than that deficiency increases obesity $(90,91,92)$. This could be taken to mean that low 25(OH)D values in obesity have no importance, being due to reverse confounding; however, this effect reduces $25(\mathrm{OH}) \mathrm{D}$ availability to target tissues, which is likely to worsen the severity of disorders associated with both obesity and T2DM. Interestingly, this additional problem in obesity can also be countered by increased glutathione provision (93, 94). Obesityrelated disorders include inflammation, which extends to tissues remote from adipose tissue (e.g. atheromatous plaque) (95). Thus, the reduced insulin secretory capacity and increased insulin resistance that follow as a result of adverse mechanistic effects of vitamin D inadequacy on liver, muscle and pancreatic islet function will increase the risks of overt T2DM, of atheromatous disease and of acute CVD events and death in obesity and T2DM. In view of these problems, patients with obesity, T2DM, or both, need higher than usual supplemental vitamin D intake to achieve adequate vitamin $\mathrm{D}$ status (e.g. $25(\mathrm{OH}) \mathrm{D}$ values $>75 \mathrm{nmol} / \mathrm{L})$ which should reduce the risks of the disorders associated with obesity and diabetes that are modulated by vitamin D (96). However, this consideration is not regularly allowed for in the routine management of patients with overweight, obesity or diabetes or in RCTs designed for assessing the potential of vitamin D supplementation for prevention or amelioration of these disorders or their sequelae.

\section{Lack of long-term RCTs}

No sufficiently long-term RCTs exist to test whether achieving long-term repletion may reduce the risks of the very chronic disorders they may aggravate, such as CVD, nor will they be, since leaving controls deficient long-term is unethical. Fortunately, on-going Finnish public health data collection following the introduction of food fortification in 2003 and the virtual abolition of deficiency from 2010 onwards may reveal reductions in the risks of these chronic disorders, for example, of T2DM since 10-20 years is the average time for increased insulin resistance to lead to overt T2DM $(39,97)$. Since overt CVD is well-known to result from progressive atherosclerosis, from adolescence or early adulthood onwards (98), any vitamin D supplementation-related benefits for CVD risks could take much longer to appear, even in Finland.

\section{Mendelian randomisation data}

A recent Mendelian randomisation (MR) study found no evidence that higher D status as judged from genetic variant associations reduces inflammation in obesity, though greater T2DM risks (+14\%) were found for genetic variants associated with lower $25(\mathrm{OH}) \mathrm{D}$ values than were found with the actual $25(\mathrm{OH}) \mathrm{D}$ assay data $(+9 \%)$ (99). Since the $25(\mathrm{OH}) \mathrm{D}$ assays had been carried out in a single laboratory, these data support the view that $25(\mathrm{OH})$ D assay variability can confound epidemiological data analyses. A further MR study supports the suggestion that reduction in vitamin $\mathrm{D}$ status is a causal determinant of T2DM risk (100). Various factors perturbing RCT outcome analyses also apply to MR analyses for 25(OH)D as an outcome, necessarily reducing MR ability to detect health benefits with specific genetic variants, especially where many subjects have $25(\mathrm{OH}) \mathrm{D}$ values on the upper or lower plateaus of observational S-shaped association curves. Re-analyses using 25(OH)D data stratified around

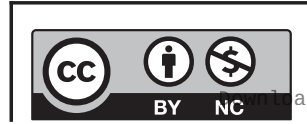

This work is licensed under a Creative Commons Attribution-NonCommercial 4.0 International License. ded from Bioscientifica.com at 04/26/2023 01:51:04AM 
specific thresholds of interest or along steep parts of the curves for observational associations of health outcome of interest with $25(\mathrm{OH}) \mathrm{D}$ might reveal genetic variant effects that are not detected using standard MR methodology (B J Boucher, unpublished observations).

\section{Future RCT design}

Allowing for the various factors reducing RCT specificity discussed above should improve our ability to get definite answers to the many persisting queries about whether known mechanistic effects of vitamin D translate into non-skeletal health benefits. The costly and labourintensive VITAL study was designed before most of these problems in vitamin D RCTs had become apparent, for example, $25(\mathrm{OH}) \mathrm{D}$ values were $<75 \mathrm{nmol} / \mathrm{L}$ in only $12.7 \%$ of those assessed. However, cancer mortality was reduced by supplementation, and further outcome analyses in initially deficient subjects will be of interest (68). Ensuring that $25(\mathrm{OH}) \mathrm{D}$ threshold values for different disorders are identified from future RCTs could encourage efforts to ensure vitamin D adequacy is achieved globally especially since the intakes, planned to achieve $50 \mathrm{nmol} / \mathrm{L}$ in $97.5 \%$ of the population by the North American Institute of Medicine (IOM), are thought to have been calculated to achieve that target in only $50 \%$ of the population (reported as ten-fold underestimates of the intakes necessary) $(101,102)$. However, the original IOM (now the National Academy of Medicine) advice remains unchanged. The guidelines on recommended daily intakes for different adult population groups continue to differ widely, even when directed solely at maintaining skeletal health and used different 25(OH)D cut-offs for protecting bone health. The IOM, for example, defines deficiency as serum $25(\mathrm{OH}) \mathrm{D}$ values $<50 \mathrm{nmol} / \mathrm{L}$ and insufficiency as $50-75 \mathrm{nmol} / \mathrm{L}$; the American Endocrine Society defines deficiency as $25(\mathrm{OH}) \mathrm{D}$ values $<75 \mathrm{nmol} / \mathrm{L}$. The UK Specialist Advisory Committee on Nutrition (SACN) defines deficiency as $25(\mathrm{OH}) \mathrm{D}$ values $<25 \mathrm{nmol} / \mathrm{L}$ and insufficiency as $25-50 \mathrm{nmol} / \mathrm{L}$. In Europe, deficiency is defined by $25(\mathrm{OH}) \mathrm{D}$ values $<50 \mathrm{nmol} / \mathrm{L}(80,103,104)$. However, all of these guidelines are either inadequate, or ineffective, since deficiency and insufficiency for bone health continue to be present globally at levels that have been described as 'pandemic' (2). Currently, vitamin D inadequacy is also postulated to increase the risks of severe COVID-19 in the current SARS-2 outbreak through various mechanisms including reduced production of antibacterial and antiviral defensins and cathelicidin, inadequate secretion of anti-inflammatory cytokines, reduced suppression of pro-inflammatory cytokine, secretion and inadequate pulmonary secretion of ACE2, a known protective factor for other acute respiratory distress syndromes $(4,105)$.

\section{Overview}

Vitamin D deficiency has no health benefits and continues to cause overt, painful and disabling bone disease while, concurrently, correction of deficiency by supplementation is reported to reduce T2DM risks and cancer mortality $(39,68)$. The problem of deficiency persists because of the poor provision of vitamin $\mathrm{D}$ by foodstuffs and because current lifestyles reduce exposure to sunlight. In addition, policy makers advising on minimal vitamin $\mathrm{D}$ intakes at the population level have relied heavily on data for health benefits from RCTs inappropriate for studying nutrients, since they can miss or obscure such benefits. Fortunately, current improvements in RCT data handling are now revealing some mechanistically predicted non-skeletal health benefits. However, while future RCTs of vitamin D must allow adequately for its biology when seeking further evidence in this area, the difficulties in ensuring that RCT design is fit for purpose does not justify the continuing acceptance of deficiency at current levels, globally, when it has been formally recognised as requiring correction for protection of skeletal health since 2011 (66).

Vitamin D deficiency severe enough to cause bone disease is avoidable through simple measures, as humankind has known for well over 100 years - these are used routinely in animal husbandry, commercial pet foods and zoos but are provided in few human populations $(106,107)$.

Vitamin D inadequacy has been well-known for $\sim 60$ years to be more common in people of south Asian than of indigenous origin in the United Kingdom and is currently suspected of being a factor that increases COVID-19 risks $(108,109)$. The UK Biobank data from 2003-2010 confirms the persistence of this problem in a reasonably large cohort of healthy volunteers and recent analyses suggest that lifestyle factors and deprivation do not fully explain these increased risks. Better lifestyle is associated with higher vitamin D status and is an obvious confounder of RCT findings of benefit with vitamin D. Obesity and diabetes, both of which specifically lower D status, are considered significant risk factors for COVID-19 severity. The adjustment of data in analyses such as those using the UK Biobank data is therefore

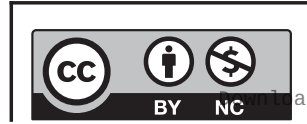

This work is licensed under a Creative Commons Attribution-NonCommercial 4.0 International License. ed from Bioscientifica.com at 04/26/2023 01:51:04AM 
complex, with many interactive confounders. This is an example of an acute disorder where crosssectional and prospective risks with vitamin D status may be less helpful that the results of trials of supplementation of deficiency in at risk communities and in early covid-19 illness for the determination of the relative roles of these risk factors for this acute illness (110).

Overall, it would be helpful if vitamin D deficiency, as currently defined for skeletal health, could be abolished in humans at the population level by measures independent of individual effort, such as the highly effective food fortification + self-supplementation programme in Finland (111). Fortification of flour plus free supplementation of high-risk groups, for example, has been proposed as a costeffective way to abolish deficiency in the United Kingdom (112). With effective programmes to reduce skeletal health risks in place, future research could focus on other aspects of vitamin D's role in human health such as establishing what further contributions improved vitamin D status may make to non-skeletal health, the correction of undesirable epigenetic effects of deficiency (especially in pregnancy where it may increase later health risks in offspring), the identification and correction of disadvantageous nutrient interactions and dealing with new problems that emerge as our understanding of the complexities of the vitamin D system increases.

\section{Declaration of interest}

The author declares that there is no conflict of interest that could be perceived as prejudicing the impartiality of this review.

\section{Funding}

This work did not receive any specific grant from any funding agency in the public, commercial, or not-for-profit sector.

\section{References}

1 Gibbs D. Rickets and the crippled child: an historical perspective. Journal of the Royal Society of Medicine 199487 729-732.

2 Holick MF. The vitamin D deficiency pandemic: approaches for diagnosis, treatment and prevention. Reviews in Endocrine and Metabolic Disorders 201718 153-165. (https://doi.org/10.1007/ s11154-017-9424-1)

3 Pereira-Santos M, Costa PR, Assis AM, Santos CA \& Santos DB. Obesity and vitamin D deficiency: a systematic review and metaanalysis. Obesity Reviews 201516 341-349. (https://doi.org/10.1111/ obr.12239)

4 Chung C, Silwal P, Kim I, Modlin RL \& Jo EK. Vitamin D-cathelicidin axis: at the crossroads between protective immunity and pathological inflammation during infection. Immune Network 202020 e12. (https://doi.org/10.4110/in.2020.20.e12)

5 Zhang R, Li B, Gao X, Tian R, Pan Y, Jiang Y, Gu H, Wang Y, Wang Y \& Liu G. Serum 25-hydroxyvitamin D and the risk of cardiovascular disease: dose-response meta-analysis of prospective studies. American Journal of Clinical Nutrition 2017105 810-819. (https://doi. org/10.3945/ajcn.116.140392)

6 Kunadian V, Ford GA, Bawamia B, Qiu W \& Manson JE. Vitamin $\mathrm{D}$ deficiency and coronary artery disease: a review of the evidence. American Heart Journal 2014167 283-291. (https://doi.org/10.1016/j. ahj.2013.11.012)

7 von Websky K, Hasan AA, Reichetzeder C, Tsuprykov O \& Hocher B. Impact of vitamin D on pregnancy-related disorders and on offspring outcome. Journal of Steroid Biochemistry and Molecular Biology 2018 180 51-64. (https://doi.org/10.1016/j.jsbmb.2017.11.008)

8 Spaight C, Gross J, Horsch A \& Puder JJ. Gestational diabetes mellitus. Endocrine Developments 20161 63-178.

9 Boucher BJ. Inadequate vitamin D status: does it contribute to the disorders comprising syndrome 'X'? British Journal of Nutrition 1998 79 315-327.

10 Moukayed M \& Grant WB. The roles of UVB and vitamin D in reducing risk of cancer incidence and mortality: a review of the epidemiology, clinical trials, and mechanisms. Reviews in Endocrine and Metabolic Disorders 201718 167-182. (https://doi.org/10.1007/ s11154-017-9415-2)

11 Forouhi NG, Luan J, Cooper A, Boucher BJ \& Wareham NJ. Baseline serum 25-hydroxy vitamin D is predictive of future glycemic status and insulin resistance: the Medical Research Council Ely Prospective Study 1990-2000. Diabetes 200857 2619-2625. (https://doi. org/10.2337/db08-0593)

12 Forouhi NG, Ye Z, Rickard AP, Khaw KT, Luben R, Langenberg C \& Wareham NJ. Circulating 25-hydroxyvitamin D concentration and the risk of type 2 diabetes: results from the European Prospective Investigation into Cancer (EPIC)-Norfolk cohort and updated metaanalysis of prospective studies. Diabetologia 201255 2173-2182. (https://doi.org/10.1007/s00125-012-2544-y)

13 Hyppönen E. Vitamin D and increasing incidence of type 1 diabetesevidence for an association? Diabetes, Obesity and Metabolism 201012 737-743. (https://doi.org/10.1111/j.1463-1326.2010.01211.x)

14 Pilz S, Tomaschitz A, März W, Drechsler C, Ritz E, Zittermann A, Cavalier E, Pieber TR, Lappe JM, Grant WB, et al. Vitamin D, cardiovascular disease and mortality. Clinical Endocrinology 201175 575-584. (https://doi.org/10.1111/j.1365-2265.2011.04147.x)

15 Giovannucci E. The epidemiology of vitamin D and cancer incidence and mortality: a review (United States). Cancer Causes and Control 200516 83-95. (https://doi.org/10.1007/s10552-004-1661-4)

16 Manousaki D, Mitchell R, Dudding T, Hawaorth S, Harroud A, Forgetta V, Shah RL, Luan J, Langenberg C, Timpson NJ, et al. Genome-wide association study for vitamin d levels reveals 69 independent loci. American Journal of Human Genetics 2020106 327-337. (https://doi.org/10.1016/j.ajhg.2020.01.017)

17 Jorde R, Sneve M, Hutchinson M, Emaus N, Figenschau Y \& Grimnes G. Tracking of serum 25-hydroxyvitamin D levels during 14 years in a population-based study and during 12 months in an intervention study. American Journal of Epidemiology $2010 \mathbf{1 7 1}$ 903-908. (https://doi.org/10.1093/aje/kwq005)

18 Holick MF. Evolutionary biology and pathology of vitamin D. Journal of Nutritional Science and Vitaminology 199238 (Special) 79-83. (https://doi.org/10.3177/jnsv.38.special_79)

19 Jablonski NG \& Chaplin G. The roles of vitamin D and cutaneous vitamin D production in human evolution and health. International Journal of Paleopathology 201823 54-59. (https://doi.org/10.1016/j. ijpp.2018.01.005)

20 Holick MF. Photosynthesis of vitamin D in the skin: effect of environmental and life-style variables. Federation Proceedings 198746 1876-1882.

21 Boucher BJ. Vitamin D status and its management for achieving optimal health benefits in the elderly. Expert Review of Endocrinology and Metabolism 201813 279-293. (https://doi.org/10.1080/17446651 .2018.1533401) 
22 Holick MF. The vitamin D deficiency pandemic: approaches for diagnosis, treatment and prevention. Reviews in Endocrine and Metabolic Disorders 201718 153-165. (https://doi.org/10.1007/ s11154-017-9424-1)

23 Lips P, Cashman KD, Lamberg-Allardt C, Bischoff-Ferrari HA, Obermayer-Pietsch B, Bianchi ML, Stepan J, El-Hajj Fuleihan G \& Bouillon R. Current vitamin D status in European and Middle East countries and strategies to prevent vitamin D deficiency: a position statement of the European Calcified Tissue Society. European Journal of Endocrinology 2019180 P23-P54. (https://doi.org/10.1530/EJE-180736)

24 Charoenngam N, Shirvani A \& Holick MF. Vitamin D for skeletal and non-skeletal health: what we should know. Journal of Clinical Orthopaedics and Trauma 201910 1082-1093. (https://doi. org/10.1016/j.jcot.2019.07.004)

25 Datta P, Philipsen PA, Olsen P, Bogh MK, Johansen P, Schmeded AV, Morling N \& Wulf HC. The half-life of 25(OH)D after UVB exposure depends on gender and vitamin $\mathrm{D}$ receptor polymorphism but mainly on the start level. Photochemical and Photobiological Sciences 201716 985-995. (https://doi.org/10.1039/C6PP00258G)

26 Bikle D \& Christakos S. New aspects of vitamin D metabolism and action - addressing the skin as source and target. Nature Reviews: Endocrinology 202016 234-252. (https://doi.org/10.1038/s41574-0190312-5)

27 Adams JS, Rafison B, Witzel S, Reyes RE, Shieh A, Chun R, Zavala K, Hewison M \& Liu PT. Regulation of the extrarenal CYP27B1hydroxylase. Journal of Steroid Biochemistry and Molecular Biology 2014 144 22-27. (https://doi.org/10.1016/j.jsbmb.2013.12.009)

28 Carlberg C. Molecular endocrinology of vitamin D on the epigenome level. Molecular and Cellular Endocrinology 2017453 14-21. (https:// doi.org/10.1016/j.mce.2017.03.016)

29 Sandler LM, Winearls CG, Fraher LJ, Clemens TL, Smith R \& O'Riordan JL. Studies of the hypercalcaemia of sarcoidosis: effect of steroids and exogenous vitamin D3 on the circulating concentrations of 1,25-dihydroxy vitamin D3. Quarterly Journal of Medicine 198453 165-180.

30 Hii CS \& Ferrante A. The non-genomic actions of vitamin D. Nutrients 20168 135. (https://doi.org/10.3390/nu8030135)

31 Kadowaki S \& Norman AW. Demonstration that the vitamin D metabolite 1,25(OH)2-vitamin D3 and not 24R,25(OH)2-vitamin D3 is essential for normal insulin secretion in the perfused rat pancreas. Diabetes 198534 315-320. (https://doi.org/10.2337/diab.34.4.315)

32 Carlberg C. Vitamin D: a micronutrient regulating genes. Current Pharmaceutical Design 201925 1740-1746. (https://doi.org/10.2174/1 381612825666190705193227)

33 Dopico XC, Evangelou M, Ferreira RC, Guo H, Pekalski ML, Smyth DJ, Cooper N, Burren OS, Fulford AJ, Hennig BJ, et al. Widespread seasonal gene expression reveals annual differences in human immunity and physiology. Nature Communications 20156 7000. (https://doi.org/10.1038/ncomms8000)

34 Carlberg C. Nutrigenomics of vitamin D. Nutrients 201911676. (https://doi.org/10.3390/nu11030676)

35 Fornari R, Francomano D, Greco EA, Marocco C, Lubrano C, Wannenes F, Papa V, Bimonte VM, Donini LM, Lenzi A, et al. Lean mass in obese adult subjects correlates with higher levels of vitamin D, insulin sensitivity and lower inflammation. Journal of Endocrinological Investigation 201538 367-372. (https://doi. org/10.1007/s40618-014-0189-z)

36 Li YC, Kong J, Wei M, Chen ZF, Liu SQ \& Cao LP. 1,25-Dihydroxyvitamin $\mathrm{D}(3)$ is a negative endocrine regulator of the renin-angiotensin system. Journal of Clinical Investigation 2002110 229-238. (https://doi.org/10.1172/JCI15219)

37 Cheng Q, Boucher BJ \& Leung PS. Modulation of hypovitaminosis D-induced islet dysfunction and insulin resistance through direct suppression of the pancreatic islet renin-angiotensin system in mice.
Diabetologia 201356 553-562. (https://doi.org/10.1007/s00125-0122801-0)

38 Cheng S, So WY, Zhang D, Cheng Q, Boucher BJ \& Leung PS. Calcitriol reduces hepatic triglyceride accumulation and glucose output Through Ca2+/CaMKK $\beta /$ AMPK activation Under insulinresistant conditions in type 2 diabetes mellitus. Current Molecular Medicine 201616 747-758. (https://doi.org/10.2174/1566524016666 160920111407)

39 Boucher BJ, Re Niroomand M, Fotouhi A, Irannejad N \& Hosseinpanah F. Does high-dose vitamin D supplementation impact insulin resistance and risk of development of diabetes in patients with pre-diabetes? A double-blind randomized controlled trial. Diabetes Research and Clinical Practice 2019148 1-9.

40 Hyppönen E \& Boucher BJ. Adiposity, vitamin D requirements, and clinical implications for obesity-related metabolic abnormalities. Nutrition Reviews 201876 678-692. (https://doi.org/10.1093/nutrit/ nuy034)

41 Hewison M, Burke F, Evans KN, Lammas DA, Sansom DM, Liu P, Modlin RL \& Adams JS. Extra-renal 25-hydroxyvitamin D3-1alphahydroxylase in human health and disease. Journal of Steroid Biochemistry and Molecular Biology 2007103 316-321. (https://doi. org/10.1016/j.jsbmb.2006.12.078)

42 Grant WB, Lahore H, McDonnell SL, Baggerly CA, French CB, Aliano JL \& Bhattoa HP. Evidence that vitamin D supplementation could reduce risk of influenza and COVID-19 infections and deaths. Nutrients 202012 988. (https://doi.org/10.3390/nu12040988)

43 Beard JA, Bearden A \& Striker R. Vitamin D and the anti-viral state. Journal of Clinical Virology 201150 194-200. (https://doi. org/10.1016/j.jcv.2010.12.006)

44 Aul AJ, Fischer PR, O'Grady JS, Mara KC, Maxson JA, Meek AM, Petterson TM \& Thacher TD. Population-based incidence of potentially life-threatening complications of hypocalcemia and the role of vitamin D deficiency. Journal of Pediatrics $201921198 . e 4-104$. e4. (https://doi.org/10.1016/j.jpeds.2019.02.018)

45 Zittermann A, Ernst JB, Prokop S, Fuchs U, Gruszka A, Dreier J, Kuhn J, Knabbe C, Berthold HK, Gouni-Berthold I, et al. Vitamin D supplementation of 4000 IU daily and cardiac function in patients with advanced heart failure: the EVITA trial. International Journal of Cardiology 2019280 117-123. (https://doi.org/10.1016/j. ijcard.2019.01.027)

46 Tetlow LC \& Woolley DE. The effects of 1 alpha,25-dihydroxyvitamin $\mathrm{D}(3)$ on matrix metalloproteinase and prostaglandin $\mathrm{E}(2)$ production by cells of the rheumatoid lesion. Arthritis Research 19991 63-70. (https://doi.org/10.1186/ar12)

47 Timms PM, Mannan N, Hitman GA, Noonan K, Mills PG, Syndercombe-Court D, Aganna E, Price CP \& Boucher BJ. Circulating MMP9, vitamin D and variation in the TIMP-1 response with VDR genotype: mechanisms for inflammatory damage in chronic disorders? QJM 200295 787-796. (https://doi.org/10.1093/ qjmed/95.12.787)

48 Kouvari M \& Panagiotakos DB. Vitamin D status, gender and cardiovascular diseases: a systematic review of prospective epidemiological studies. Expert Review of Cardiovascular Therapy 2019 17 545-555. (https://doi.org/10.1080/14779072.2019.1637255)

49 Rejnmark L, Bislev LS, Cashman KD, Eriksdottir G, Gaksch M, Grubler M, Grimnes G, Gudnason V \& LIps P. Non-skeletal health effects of vitamin D supplementation: a systematic review on findings from meta-analyses summarizing trial data. PLOS ONE 2017 12 e0180512.

50 Vallejo-Vaz AJ, Corral P, Schreier L \& Ray KK. Triglycerides and residual risk. Current Opinion in Endocrinology, Diabetes, and Obesity 202027 95-103. (https://doi.org/10.1097/MED.0000000000000530)

51 Dibaba DT. Effect of vitamin D supplementation on serum lipid profiles: a systematic review and meta-analysis. Nutrition Reviews 201977 890-902. (https://doi.org/10.1093/nutrit/nuz037) https://ec.bioscientifica.com https://doi.org/10.1530/EC-20-0274 (c) 2020 The authors Published by Bioscientifica Ltd

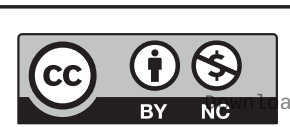

This work is licensed under a Creative Commons Attribution-NonCommercial 4.0 International License. ded from Bioscientifica.com at 04/26/2023 01:51:04AM 
52 McDonnell SL, Baggerly C, French CB, Garland CF, Gorham ED, Lappe JM \& Heaney RP. Serum 25-hydroxyvitamin D concentrations $\geq 40 \mathrm{ng} / \mathrm{ml}$ are associated with $>65 \%$ lower cancer risk: pooled analysis of randomized trial and prospective cohort study. PLOS ONE 201611 e0152441.

53 Grant WB, Al Anouti F \& Moukayed M. Targeted 25-hydroxyvitamin D concentration measurements and vitamin $\mathrm{D}_{3}$ supplementation can have important patient and public health benefits. European Journal of Clinical Nutrition 202074 366-376. (https://doi.org/10.1038/ s41430-020-0564-0)

54 Jukic AMZ, Baird DD, Weinberg CR, Wilcox AJ, McConnaughey DR \& Steiner AZ. Pre-conception 25-hydroxyvitamin D (25(OH)D) and fecundability. Human Reproduction 201934 2163-2172. (https://doi. org/10.1093/humrep/dez170)

55 Tamblyn JA, Hewison M, Wagner CL, Bulmer JN \& Kilby MD Immunological role of vitamin $\mathrm{D}$ at the maternal-fetal interface. Journal of Endocrinology 2015224 R107-R121. (https://doi. org/10.1530/JOE-14-0642)

56 Wagner CL, Hollis BW, Kotsa K, Fakhoury H \& Karras SN. Vitamin $\mathrm{D}$ administration during pregnancy as prevention for pregnancy, neonatal and postnatal complications. Reviews in Endocrine and Metabolic Disorders 201718 307-322. (https://doi.org/10.1007/ s11154-017-9414-3)

57 Pérez-López FR, Pilz S \& Chedraui P. Vitamin D supplementation during pregnancy: an overview. Current Opinion in Obstetrics and Gynecology 202032 316-321. (https://doi.org/10.1097/ gco.0000000000000641)

58 Hossein-Nezhad A \& Holick MF. Optimize dietary intake of vitamin D: an epigenetic perspective. Current Opinion in Clinical Nutrition and Metabolic Care 201215 567-579. (https://doi.org/10.1097/ MCO.0b013e3283594978)

59 Holick MF. The vitamin D deficiency pandemic and consequences for non-skeletal health; mechanisms of action. Molecular Aspects of Medicine 201229 361-368.

60 Lappe JM \& Heaney RP. Why randomized controlled trials of calcium and vitamin D sometimes fail. Dermato-Endocrinology 20124 95-100. (https://doi.org/10.4161/derm.19833)

61 Martineau AR, Jolliffe DA, Hooper RL, Greenberg L, Aloia JF, Bergman P, Dubnov-Raz G, Esposito S, Ganmaa D, Ginde AA, et al. Vitamin D supplementation to prevent acute respiratory tract infections: systematic review and meta-analysis of individual participant data. BMJ 2017356 i6583. (https://doi.org/10.1136/bmj. i6583)

62 Sanders KM, Stuart AL, Williamson EJ, Simpson JA, Kotowicz MA, Young D \& Nicholson GC. Annual high-dose oral vitamin D and falls and fractures in older women: a randomized controlled trial. JAMA 2010303 1815-1822. (https://doi.org/10.1001/jama.2010.594)

$63 \mathrm{Hu}$ Z, Chen J, Sun X, Wang L \& Wang A. Efficacy of vitamin D supplementation on glycemic control in type 2 diabetes patients: a meta-analysis of interventional studies. Medicine 201998 e14970. (https://doi.org/10.1097/MD.0000000000014970)

64 He S, Yu S, Zhou Z, Wang C, Wu Y \& Li W. Effect of vitamin D supplementation on fasting plasma glucose, insulin resistance and prevention of type 2 diabetes mellitus in non-diabetics: a systematic review and meta-analysis. Biomedical Reports 20188 475-484. (https://doi.org/10.3892/br.2018.1074)

65 Scragg R. Emerging evidence of thresholds for beneficial effects from vitamin D supplementation. Nutrients 201810 561. (https://doi. org/10.3390/nu10050561)

66 Ross AC, Manson JE, Abrams SA, Aloia JF, Brannon PM, Clinton SK, Durazo-Arvizu RA, Gallagher JC, Gallo RL, Jones G, et al. The 2011 report on dietary reference intakes for calcium and vitamin $\mathrm{D}$ from the Institute of Medicine: what clinicians need to know. Journal of Clinical Endocrinology and Metabolism 201196 53-58. (https://doi. $\operatorname{org} / 10.1210 /$ jc.2010-2704)
67 von Hurst PR, Stonehouse W \& Coad J. Vitamin D supplementation reduces insulin resistance in South Asian women living in New Zealand who are insulin resistant and vitamin D deficient - a randomised, placebo-controlled trial. British Journal of Nutrition 2010 103 549-555. (https://doi.org/10.1017/S0007114509992017)

68 Manson JE, Bassuk SS, Buring JE \& VITAL Research Group. Principal results of the vitamin D and OmegA-3 TriaL (VITAL) and updated meta-analyses of relevant vitamin D trials. Journal of Steroid Biochemistry and Molecular Biology 2020198 105522. (https://doi. org/10.1016/j.jsbmb.2019.105522)

69 Barragry JM, France MW, Corless D, Gupta SP, Switala S, Boucher BJ $\&$ Cohen RD. Intestinal cholecalciferol absorption in the elderly and in younger adults. Clinical Science and Molecular Medicine 197855 213-220. (https://doi.org/10.1042/cs0550213)

70 Hypponen E \& Boucher BJ. Adiposity, vitamin D requirements, and clinical implications for obesity-related metabolic abnormalities. Nutrition Reviews 201876 678-692. (https://doi.org/10.1093/nutrit/ nuy034)

71 Grant WB, Boucher BJ, Bhattoa HP \& Lahore H. Why vitamin D clinical trials should be based on 25-hydroxyvitamin D concentrations. Journal of Steroid Biochemistry and Molecular Biology 2018177 266-269. (https://doi.org/10.1016/j.jsbmb.2017.08.009)

72 Kahwati LC, Weber RP, Pan H, Gourlay M, LeBlanc E, CokerSchwimmer M \& Viswanathan M. Vitamin D, calcium, or combined supplementation for the primary prevention of fractures in community-dwelling adults: evidence report and systematic review for the US Preventive Services Task Force. JAMA 2018319 1600-1612. (https://doi.org/10.1001/jama.2017.21640)

73 Boucher BJ. Calcium supplements may increase the risk of cardiovascular events in postmenopausal women. Evidence-Based Medicine 201217 16-17. (https://doi.org/10.1136/ebm.2011.100113)

74 Dai Q, Zhu X, Manson JE, Song Y, Li X, Franke AA, Costello RB, Rosanoff A, Nian H, Fan L, et al. Magnesium status and supplementation influence vitamin D status and metabolism: results from a randomized trial. American Journal of Clinical Nutrition 2018 108 1249-1258. (https://doi.org/10.1093/ajcn/nqy274)

75 Carlberg C \& Campbell MJ. Vitamin D receptor signaling mechanisms: integrated actions of a well-defined transcription factor. Steroids $2013 \mathbf{7 8}$ 127-136. (https://doi.org/10.1016/j. steroids.2012.10.019)

76 Elshama SS, Osman HE, El-Kenawy Ael Ael-M \& Youseef HM. Comparison between the protective effects of vitamin $\mathrm{K}$ and vitamin A on the modulation of hypervitaminosis D3 short-term toxicity in adult albino rats. Turkish Journal of Medical Sciences 201646 524-538. (https://doi.org/10.3906/sag-1411-6)

77 Cheng TY, Lacroix AZ, Beresford SA, Barnett MJ, Beresford SA, LaCroix AZ, Zheng Y \& Neuhouser ML. Vitamin D intake and lung cancer risk in the Women's Health Initiative. American Journal of Clinical Science 201398 1002-1011.

78 van Ballegooijen AJ, Pilz S, Tomaschitz A, Grübler MR \& Verheyen N. The synergistic interplay between vitamins $\mathrm{D}$ and $\mathrm{K}$ for bone and cardiovascular health: a narrative review. International Journal of Endocrinology 20172017 7454376. (https://doi. org/10.1155/2017/7454376)

79 Scientific Advisory Committee on Nutrition. Vitamin D and Health. London, UK: Public Health England, 2016. (available at: https://www. gov.uk/government/publications/sacn-vitamin-d-and-health-report)

80 Holick MF, Binkley NC, Bischoff-Ferrari HA, Gordon CM, Hanley DA, Heaney RP, Murad MH, Weaver CM \& Endocrine Society. Evaluation, treatment, and prevention of vitamin D deficiency: an Endocrine Society clinical practice guideline. Journal of Clinical Endocrinology and Metabolism 201196 1911-1930. (https://doi.org/10.1210/jc.20110385)

81 Peiris AN, Youssef D \& Grant WB. Secondary hyperparathyroidism: benign bystander or culpable contributor to adverse health https://ec.bioscientifica.com https://doi.org/10.1530/EC-20-0274 (c) 2020 The authors Published by Bioscientifica Ltd

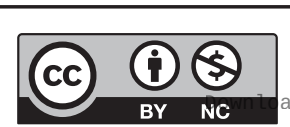

This work is licensed under a Creative Commons Attribution-NonCommercial 4.0 International License. ded from Bioscientifica.com at 04/26/2023 01:51:04AM 
outcomes? Southern Medical Journal 2012105 36-42. (https://doi org/10.1097/SMJ.0b013e31823c4155)

82 Bedner M, Lippa KA \& Tai SS. An assessment of 25-hydroxyvitamin $\mathrm{D}$ measurements in comparability studies conducted by the vitamin D metabolites quality assurance program. Clinica Chimica Acta: International Journal of Clinical Chemistry 2013426 6-11. (https://doi. org/10.1016/j.cca.2013.08.012)

83 Carter GD, Berry J, Durazo-Arvizu R, Gunter E, Jones G, Jones J, Makin HLJ, Pattni P, Sempos CT, Twomey P, et al. Hydroxyvitamin D assays: an historical perspective from DEQAS. Journal of Steroid Biochemistry and Molecular Biology 2018177 30-35. (https://doi. org/10.1016/j.jsbmb.2017.07.018)

84 Carter GD. Accuracy of 25-hydroxyvitamin D assays: confronting the issues. Current Drug Targets 201112 19-28. (https://doi. org/10.2174/138945011793591608)

85 Berry DJ, Dutton J, Fraser WD, Järvelin MR \& Hyppönen E. Harmonization study between LC-MS/MS and DiaSorin RIA for measurement of 25-hydroxyvitamin D concentrations in a large population survey. Journal of Clinical Laboratory Analysis 201731 e22049. (https://doi.org/10.1002/jcla.22049)

86 Sempos CT, Heijboer AC, Bikle DD, Bollersley J, Bouillon R, Brannon PM, DeLuca HF, Jones G, Munns CF, Bilezikian JP, et al. Vitamin D assays and the definition of hypovitaminosis D: results from the first International Conference on Controversies in Vitamin D. British Journal of Clinical Pharmacology 201884 2194-2207. (https://doi.org/10.1111/bcp.13652)

87 Trummer O, Schweighofer N, Haudum CW, Trummer C, Pilz S, Theiler-Schwetz V, Keppel MH, Grubler M, Pieber TR, Renner W, et al. Genetic components of 25-hydroxyvitamin D increase in three randomized controlled trials. Journal of Clinical Medicine 20209570. (https://doi.org/10.3390/jcm9020570)

88 Barry EL, Rees JR, Peacock JL, Mott LA, Amos CI, Bostick RM, Figueiredo JC, Ahnen DJ, Bresalier RS, Burke CA, et al. Genetic variants in CYP2R1, CYP24A1, and VDR modify the efficacy of vitamin D3 supplementation for increasing serum 25-hydroxyvitamin D levels in a randomized controlled trial. Journal of Clinical Endocrinology and Metabolism 201499 E2133-E2137. (https://doi.org/10.1210/jc.2014-1389)

89 Chun RF, Shieh A, Gottlieb C, Yacoubian V, Wang J, Hewison M \& Adams JS. Vitamin D binding protein and the biological activity of vitamin D. Frontiers in Endocrinology 201910 718. (https://doi. org/10.3389/fendo.2019.00718)

90 Bouillon R \& Bikle D. Vitamin D metabolism revised: fall of dogmas. Journal of Bone and Mineral Research 201934 1985-1992. (https://doi org/10.1002/jbmr.3884)

91 Mutt SJ, Hyppönen E, Saarnio J, Järvelin MR \& Herzig KH. Vitamin D and adipose tissue-more than storage. Frontiers in Physiology 20145 228. (https://doi.org/10.3389/fphys.2014.00228)

92 Aatsinki SM, Elkhwanky MS, Kummu O, Karpale M, Buler M, Viitala P, Rinne V, Mutikainen M, Taven P, Franko A, et al. Fastinginduced transcription factors repress vitamin $\mathrm{D}$ bioactivation, a mechanism for vitamin D deficiency in diabetes. Diabetes 201968 918-931. (https://doi.org/10.2337/db18-1050)

93 Boucher BJ. Inadequate vitamin D status: does it contribute to the disorders comprising syndrome 'X'? British Journal of Nutrition 1998 79 315-327. (https://doi.org/10.1079/bjn19980055)

94 Jain SK, Parsanathan R, Achari AE, Kanikarla-Marie P \& Bocchini JA Jr. Glutathione stimulates vitamin D regulatory and glucose-metabolism genes, lowers oxidative stress and inflammation, and increases 25-hydroxy-vitamin D levels in blood: a novel approach to treat 25-hydroxyvitamin D deficiency. Antioxidants and Redox Signaling 201829 1792-1807. (https://doi.org/10.1089/ars.2017.7462)

95 Boutens L, Hooiveld GJ, Dhingra S, Cramer RA, Netea MG $\&$ Stienstra R. Unique metabolic activation of adipose tissue macrophages in obesity promotes inflammatory responses. Diabetologia 201861 942-953. (https://doi.org/10.1007/s00125-0174526-6)

96 Drincic A, Fuller E, Heaney RP \& Armas LA. 25-Hydroxyvitamin D response to graded vitamin $\mathrm{D}_{3}$ supplementation among obese adults. Journal of Clinical Endocrinology and Metabolism 201398 4845-4851. (https://doi.org/10.1210/jc.2012-4103)

97 Paalanen L, Härkänen T \& Tolonen H. Protocol of a research project 'Projections of the burden of disease and disability in Finland health policy prospects' using cross-sectional health surveys and register-based follow-up. BMJ Open 20199 e029338. (https://doi. org/10.1136/bmjopen-2019-029338)

98 Berenson GS, Srinivasan SR, Nicklas TA \& Webber LS. Cardiovascular risk factors in children and early prevention of heart disease. Clinical Chemistry 198834 B115-B122.

99 Palaniswamy S, Gill D, De Silva NM, Lowry E, Jokelainen J, Karhu T, Mutt SJ, Dehghan A, Sliz E, Chasman DI, et al. Could vitamin $\mathrm{D}$ reduce obesity-associated inflammation? Observational and Mendelian randomization study. American Journal of Clinical Nutrition 2020111 1036-1047. (https://doi.org/10.1093/ajcn/nqaa056)

100 Lu L, Bennett DA, Millwood IY, Parish S, McCarthy MI, Mahajan A, Lin X, Bragg F, Guo Y, Holmes MV, et al. Association of vitamin D with risk of type 2 diabetes: a Mendelian randomisation study in European and Chinese adults. PLoS Medicine 201815 e1002566. (https://doi.org/10.1371/journal.pmed.1002566)

101 Heaney RP \& Holick MF. Why the IOM recommendations for vitamin D are deficient. Journal of Bone and Mineral Research 201126 455-457. (https://doi.org/10.1002/jbmr.328)

102 Hathcock JN, Shao A, Vieth R \& Heaney R. Risk assessment for vitamin D. American Journal of Clinical Nutrition 200785 6-18. (https://doi.org/10.1093/ajcn/85.1.6)

103 Holick MF, Binkley NC, Bischoff-Ferrari HA, Gordon CM, Hanley DA, Heaney RP, Murad MH, Weaver CM \& Endocrine Society. Evaluation, treatment, and prevention of vitamin D deficiency: an Endocrine Society clinical practice guideline. Journal of Clinical Endocrinology and Metabolism 201196 1911-1930. (https://doi.org/10.1210/jc.20110385)

104 European Food Safety Authority. Vitamin D: EFSA sets dietary reference values. Parma, Italy: EFSA, 2016. (available at: https://www. efsa.europa.eu/en/press/news/161028)

105 Grant WB, Baggerly CA \& Lahore H. Reply: 'Vitamin D supplementation in influenza and COVID-19 infections'. Comment on: evidence that vitamin D supplementation could reduce risk of influenza and COVID-19 infections and deaths. Nutrients 2020121620.

106 Uhl EW. The pathology of vitamin D deficiency in domesticated animals: an evolutionary and comparative overview. International Journal of Paleopathology 201823 100-109. (https://doi.org/10.1016/j. ijpp.2018.03.001)

107 European Agency for the Evaluation of Medicinal Products, Veterinary Medicines Evaluation Unit. Committee for veterinary medicinal products vitamin D summary report. London, UK: EMEA 1998. (available at: https://www.ema.europa.eu/en/documents/mrlreport/vitamin-d-summary-report-committee-veterinary-medicinalproducts_en.pdf)

108 Bivins R. 'The English disease' or 'Asian rickets'? Medical responses to postcolonial immigration. Bulletin of the History of Medicine $2007 \mathbf{8 1}$ 533-568. (https://doi.org/10.1353/bhm.2007.0062)

109 Boucher BJ, Mannan N, Noonan K, Hales CN \& Evans SJ. Glucose intolerance and impairment of insulin secretion in relation to vitamin D deficiency in east London Asians. Diabetologia 199538 1239-1245. (https://doi.org/10.1007/BF00422375)

111 Darling AL, Blackbourn DJ, Ahmadi KR \& Lanham-New SA. Very high prevalence of 25-hydroxyvitamin D deficiency in $n$ https://ec.bioscientifica.com https://doi.org/10.1530/EC-20-0274 (c) 2020 The authors Published by Bioscientifica Ltd

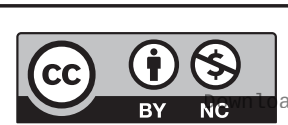

This work is licensed under a Creative Commons Attribution-NonCommercial 4.0 International License. ded from Bioscientifica.com at 04/26/2023 01:51:04AM 
6433 UK South Asian adults: analysis of the UK Biobank Cohort. British Journal of Nutrition 202022 1-34. (https://doi.org/10.1017/ S0007114520002779)

112 Jääskeläinen T, Itkonen ST, Lundqvist A, Erkkola M, Koskela T, Lakkala K, Dowling KG, Hull GL, Kröger H, Karppinen J, et al. The positive impact of general vitamin $\mathrm{D}$ food fortification policy on vitamin D status in a representative adult Finnish population: evidence from an 11-y follow-up based on standardized 25-hydroxyvitamin D data. American Journal of Clinical Nutrition 2017105 1512-1520. (https://doi.org/10.3945/ ajcn.116.151415)

113 Aguiar M, Andronis L, Pallan M, Högler W \& Frew E. The economic case for prevention of population vitamin D deficiency: a modelling study using data from England and Wales. European Journal of Clinical Nutrition 202074 825-833. (https://doi.org/10.1038/s41430-0190486-x)

Received in final form 17 June 2020

Accepted 11 August 2020

Accepted Manuscript published online 11 August 2020
This work is licensed under a Creative Commons Attribution-NonCommercial 4.0 International License. 